\title{
Actions of the Judicial Commission of the International Committee on Systematic Bacteriology on Requests for Opinions Published in 1982
}

\author{
LAWRENCE G. WAYNE ${ }^{\dagger}$ \\ Veterans Administration Medical Center, Long Beach, California 90822
}

\begin{abstract}
Three requests for Opinions were published in 1982. Two of these, one requesting rejection of the name Nocardia farcinica and one requesting substitution of the family name Escherichiaceae for Enterobacteriaceae, have been denied. The third, requesting confirmation of types designated in the Approved Lists as nomenclatural types, has been awarded.
\end{abstract}

The statutes of the International Committee on Systematic Bacteriology, which are printed in the International Code of Nomenclature of Bacteriology (6), provide for formal publication of Opinions that have been issued by the Judicial Commission of the International Committee. However, there is no provision for formal publication of denials of Opinions that have been requested, other than as minutes of the meetings of the Judicial Commission. To minimize uncertainty in the scientific community in th: period between resolution of some questions by mail ballot of the Judicial Commission and the appearance of the dicisions in minutes of the quadrennial meetings, we have established the practice of publishing interim reports of decisions. This is such a report on the resolution of three Requests for Opinions upon which votes were taken 12 months or more after publication of the Requests.

Status of the name Nocardia farcinica. Recognizing that some strains bearing the name $N$. farcinica were members of the genus Nocardia, but that others belonged in the genus Mycobacterium, Tsukamura (9) proposed rejection of the name $N$. farcinica as a nomen dubium. However, Chamoiseau (1) had already established two species, Mycobacterium senegalense and Mycobacterium farcinogenes, to accommodate the farcy-associated strains of mycobacteria, thus eliminating this source of confusion. Furthermore, Tsukamura himself recognized a distinct taxonomic cluster of nocardiae (10) that included strain ATCC 3318, which is the type strain of $N$. farcinica (7). The Judicial Commission could find no compelling reason to reject $N$. farcinica and declined to award the requested Opinion. $N$. farcinica Trevisan 1889 remains a valid species as shown in the Approved Lists of Bacterial Names (7).

Nomenclature of Enterobacteriaceae. Although the spelling of the family name Enterobacteriaceae and the assignment of the genus Escherichia as its type genus are not in conformity with the Bacteriological Code (6), the Judicial Commission conserved them in Opinion $15(2,4)$. The Judicial Commission denied a later request that Opinion 15 be overturned and that Enterobacteraceae, with the type genus Enterobacter, be substituted $(5,11)$. Subsequently, Groodfellow and Trüper proposed that the name Escherichiaceae be substituted for Enterobacteriaceae (3). The Judicial Commission recognizes the irregularity of the existing nomenclature, but notes that the exception in Opinion 15 was awarded under essentially the same rules that apply today.

† Chairman, Judicial Commission, International Committee on Systematic Bacteriology.
Since no new information was introduced in the recent proposals, the present Judicial Commission has voted not to override the Opinion issued by the prior Judicial Commission. The family name Enterobacteriaceae remains valid, as does Escherichia as its type genus.

Status of nomenclatural types. The Approved Lists of Bacterial Names (7) represent a new base line for bacterial nomenclature. There are a few inconsistencies between the nomenclatural types that appear in the Approved Lists and the historically designated types. To avoid confusion and to assure that the Approved Lists serve their base-line function, Sneath has proposed that the Judicial Commission confirm that the types in the Approved Lists are the nomenclatural types, but without prejudice to the powers of the Commission to amend them on an individual basis (8). The Judicial Commission has voted to award this Opinion. The types in the Approved Lists are the nomenclatural types unless and until they are changed by formal Judicial Commission action in individual cases. This Opinion will be numbered and published formally in a subsequent issue of the International Journal of Systematic Bacteriology.

\section{LITERATURE CITED}

1. Chamoiseau, G. 1979. Etiology of farcy in African bovines: nomenclature of the causal organisms Mycobacterium farcinogenes Chamoiseau and Mycobacterium senegalense (Chamoiseau) comb. nov. Int. J. Syst. Bacteriol. 29:407-410.

2. Editorial Board of the International Committee on Bacteriological Nomenclature. 1958. Opinion 15. Conservation of the family name Enterobacteriaceae, of the name of the type genus, and designation of the type species, p. 162. In International code of nomenclature of bacteria and viruses. The Iowa State University Press, Ames.

3. Goodfellow, M., and H. G. Trüper. 1982. Escherichiaceae nom. nov., a name to replace Enterobacteriaceae. Request for an Opinion. Int. J. Syst. Bacteriol. 32:383.

4. Judicial Commission of the International Committee on Bacterial Nomenclature. 1958. Conservation of the family name Enterobacteriaceae, of the name of the type genus, and designation of the type species. Int. Bull. Bacteriol. Nomencl. Taxon. 8:73-74.

5. Lapage, S. P. 1979. Proposal of Enterobacteraceae nom. nov. as a substitute for the illegitimate but conserved name Enterobacteriaceae Rahn 1937. Request for an Opinion. Int. J. Syst. Bacteriol. 29:265-266.

6. Lapage, S. P., P. H. A. Sneath, E. F. Lessel, V. B. D. Skerman, H. P. R. Seeliger, and W. A. Clark (ed.). 1975. International code of nomenclature of bacteria. 1975 Revision. American Society for Microbiology, Washington, D.C.

7. Skerman, V. B. D., V. McGowan, and P. H. A. Sneath (ed.). 1980. Approved lists of bacterial names. Int. J. Syst. Bacteriol. 30:225-420. 
8. Sneath, P. H. A. 1982. Status of nomenclatural types in the Approved Lists of Bacterial Names. Request for an Opinion. Int. J. Syst. Bacteriol. 32:459-460.

9. Tsukamura, M. 1982. Rejection of the name Nocardia farcinica Trevisan 1889. Request for an Opinion. Int. J. Syst. Bacteriol. 32:235-236.
10. Tsukamura, M. 1982. Numerical analysis of the taxonomy of nocardiae and rhodococci. Microbiol. Immunol. 26:1101-1119.

11. Wayne, L. G. 1982. Actions of the Judicial Commission of the International Committee on Systematic Bacteriology on Requests for Opinions published between July 1979 and April 1981. Int. J. Syst. Bacteriol. 32:464-465. 